\title{
The Supremacy of Religious and Theological Education and Its Importance to Church Administrators
}

\author{
Adegbite, Deborah Doyinsola
}

Adeleke University, Ede, Osun State,Nigeria

\section{Doi:10.5901/jesr.2014.v4n7p161}

Abstract

The background to this paper is that in academics, religious studies is not given its due respect and many church administrators today see no reasonable ground for studying Theology; the belief is that Theology is not needed for ministerial competence either as Pastors, Prophets, Teachers, Evangelists etc. They operate with an erroneous motto: "You shall receive Power not a Theological College Certificate" which is a misinterpretation of Acts 1:8. This paper explored the importance of Theological Education to Church Administration in the context of the Scripture (Hos. 4:5). The methodology adopted a Reader Response Criticism approach and Historical-Critical method with emphasis on the exegesis of both Hosea 4:6. The results showed that many people are being misled under the umbrella of prophecy and direction of the Holy Spirit simply because of the lack of Theological Education. The paper concluded that since Jesus taught his disciples for about three and a half years before telling them to wait for the Power of the Holy Spirit, all Christian administrators should take Theological training seriously to avoid becoming blind guides to their members.

Keywords: Religious Education, Administration, Theology, Law, Medicine

\section{Introduction}

Theological Education ${ }^{1}$ here is referring to the process of acquiring knowledge about how to interpret the Scriptures and

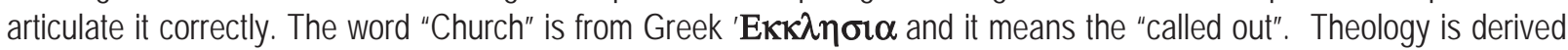

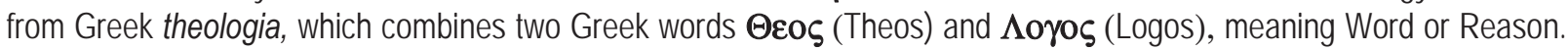
These two words $\Theta \varepsilon \circ \varsigma+\Lambda o \gamma o \varsigma=\Theta \varepsilon \circ \lambda$ oyo $\varsigma$ combine to mean discourses about God; reasoning about God or even the praise of God. Alister McGrath asserts that "theology is systematic analysis of the nature, purposes and activity of God."2 Thomas Aquinas, in his Summa Theologiae, also agreed that theology is taught by God, taught of God and leads to God. Ian T. Ramsey, was of the opinion that education was the creature of religion ${ }^{3}$ that is, religion begat education. It is important to know that any Religion without Theology is fanaticism and Theologian who is not religious is a potential atheist. Therefore, Theology is at the centre of the church administration.

\section{Values of Theological Education}

1. It informs the administrator on what must be known

2. It instructs the administrator on what to do when others fail

3. It enlightens the administrator on what to teach

4. It places God at the centre of religious administrations

5. It supplies strength when the leader is weak - knowledge is power

6. It safeguards against error in religious practices

7. It supplies wisdom to repair the damage done by others

8. It supplies authoritative statement

9. It supplies boldness to the coward

10. It gives light when darkness abounds

11. It provides wise answers to foolish questions

1 Theological education here can be used inter-changeably with Christian Religious Education.

${ }^{2}$ A. E. McGrath; Historical Theology: An Introduction to the History of Christian Thought; London: Blackwell; 1998; p. 2.

3 I. T. Ramsay; The Fourth R: The Durham Report on Religious Education; London: SPCK; 1970; p. 1. 
12. It humbles the arrogant opponents

13. It protects the unity of the body of Christ

14. It preserves God's standard in religiosity

\section{The Supremacy of Theology and Religious Education over Others}

Human beings are grammatically divided into three: I, You and s/he. Human life basically depends on three things to survive: water, air and food; a complete sentence will have three parts: subject, object and copula. Also, in the same way, total human enjoyment depends on three things: Law, Medicine \& Theology. Failure to abide with Law, the offender may be jailed or even killed. Failure to abide with medical rules, the offender may be sick or even die. Also, failure to be religious ${ }^{4}$, the offender will have serious spiritual problems that both law and medicine cannot sort out. It is possible to suffer in this life and the life to come. These three subjects (Law, Medicine and Theology) therefore, naturally complete human life circle and apart from these three subjects, there is no other University subject that stands alone.

Geography: (being the study of all the physical features of the Earth's surface) the role of the Department of Geography is to understand what (the earth) God created from the Genesis story ${ }^{5}$. It is for the purpose of understanding the elementary Theology when the bible says "in the beginning God created the heavens and the earth..." (Gen.1:1).

Biology: it is from Greek 'bios', meaning life. It was a simple biblical sentence that created the Departments of Biology in Universities throughout the world - "God breathed the breath of life ..." and this is the area of specialization of those who study Biology; it also links with John 1:14 where the bible says "In Him (Christ) was life..."

Languages: all kinds of languages, such as, German, French, English, Yoruba, Hausa, etc. are meant to sort out the problem that Theology created at the Tower of Babel.

Mathematics: "Be fruitful and multiply ..." is the Theological statement that created the Department of Mathematical studies and then human beings began multiplying and subtracting whatever.

Physics and Chemistry: are the children of the union between Geography and Biology in other to sort out the problem of relationship between matter and substances.

Agricultural Science: this department in any University is meant for one single purpose - to re-directing humanity back into his original duty in the Garden of Eden - "till the ground..." (Gen.1:28) it is also trying to get rid of God's curse from the earth "cursed is the ground for thy sake..." (Gen.3:17).

Education: The Faculty of Education is set up in obedience to the biblical instruction -"Teach up a child..."(Pro.22:6).

Economics: this department helps with standardizing the economic instruction of God (managing goods, production and gains). For example, the Bible says that "You will reap whatever you sow" (Gal.6:7). The Bible also advises that we should give our 'first' to God in order to get better gain, "give and it shall be given unto you..." (Lk. 6:38).

Science \& Technology: including Computer Science are courses created to manage the problems created by human beings as a result of the fall. Note that in Adam, humanity ate the forbidden fruit and therefore, man became small gods who can create. If man was contented with the Edenic conditions, there would have been no need for science and technology. The book of Genesis says that the fallen man began science \& technology by manufacturing weapons of war as well as musical instruments (Gen.4).

ICT: Information \& Communication Technology came on board when human beings disagreed with Jesus' instruction-pray "ceaselessly". A person who prays "ceaselessly" will have little or no time to watch television or browse on the internet.

Political Science and all forms of Politics are set up for learning how humans can rule themselves after refusing to stay under God's rule. Politics was born and Dispensationalists call it Dispensation of Human Government.

Philosophy and Social Sciences is a Department created as expansion of the book of Proverbs and Ecclesiastics. If these two books of the Bible are well understood, the reader can become an expert in the course without attending any University. For example, the book of Proverbs simply said "Go to the ants thou sluggard, consider her ways and be ye wise" and before we know it people set up Department of Zoology in order to study all kinds of animals in order to be wise!

Theology, therefore, is the mother of all subjects; it is the greatest, we may leave Law and Medicine to struggle for the second position. Law bows for Theology because its existence depends on Theology, the first laws were produced by Theology "...thou shall not..." (Ex.20) therefore, Law as an academic discipline is a tiny part of Theology because it is

${ }^{4}$ Religion in this context is "the recognition of all our duties as divine commands." (Immanuel Kant)

5 If the creation story is taken for granted as absolute truth 
simply an extension of the law that was given in the Garden of Eden and also the Mosaic Law. Apart from that, it is Theology that will jail the Lawyers and the Judges at the end of their lives when the final judgement comes if they refuse to bow for theology.

Medicine bows for Theology and profusely confesses that the "medical doctors care but God cures." In fact, Theology confirms that Medical Doctors are fake because it was written "I am the Jehovah Rapha, "the Lord your healer"(Ex.15:26). This simply dismisses the job of the medical doctors, although they still receives salaries but for the job done by God.

Medicine and Law are in the Kingdom of God; this is because the Bible asserts that no unclean thing will be permitted to enter (Rev.21:27). It automatically follows that at least there will be immigration and custom officers, which implies immigration laws. Also there is a tree of which its leaf will heal the nations (Rev.22:2). Of course, Theology is also in the Kingdom of God because the "Theos" of theology is the President of the new Kingdom; all other subjects are missing in the new world! If these arguments are reasonable and logically coherent, then it can be confidently declared that the graduates in Religious Studies and Theology are the greatest of all graduates in academic disciplines.

\section{History of Theological Education}

Education, whether formal or informal, developed from the human struggle for survival and enlightenment. Before people began to read and write, they developed skills that grew into cultural and educational patterns which must be passed on from adults to children. From about 3000 bc in ancient Egypt, people were taught both religion and education (i.e. principles of writing, the sciences, mathematics, and architecture) by the temple priests. From about $1200 \mathrm{bc}$ priests in India also taught the principles of the Veda, the sacred texts of Hinduism, as well as science, grammar, and philosophy. Some of the Greek philosophies are religious in nature. Examples are Socrates' philosophy (Socraticism) which consisted of questions about the meaning of life, truth, and justice. He forced his students to think deeply about things which religion counts as important. Plato also taught about a world of perfect ideas, Aristotle also discovered natural laws which is used today as the Cosmological argument for the existence of God. Some of the Early Church Fathers such as Clement of Alexandria and Origen are influenced by their philosophy.

Jewish children were introduced to education through religion (i.e. by studying the Torah) inside the synagogues and other places of worship. Jesus taught his disciples for about three and a half years. Also in the New Testament, the Epistle to the Romans seems to be a good example of theological exposition because of the way Apostle Paul pictured the sinful situation of man and his need for justification by faith which implicitly brings about a possibility of universal salvation. Origen, a great $3^{\text {rd }}$ century theologian taught at the Alexandrian Catechetical School and his theological work was systematized in his: "De Principiis" (On First Principles). The $5^{\text {th }}$ century great theologian was Augustine of Hippo whose principal work is "The City of God" where he made use of his Manichean's dualism to present human history as a struggle between the forces of good and evil. His article "On the Trinity" is another wonderful theological work.

Thomas Aquinas's Summa Theologica was an important theological work of the Middle Ages despite the fact that the work was not finished before he died in 1274. In the 11th century medieval scholars developed Scholasticism which used both reason and revelations from the Bible. Universities began in the $12^{\text {th }}$ and $13^{\text {th }}$ centuries and they only taught theology, law, and medicine. In the 15th century, it was Christianity that shaped both the society and the educational system and the $16^{\text {th }}$ century Protestant educators wrote religious books (catechisms). But after the Reformation era, there was little to say because the theological division between the Roman Catholic and Protestant orthodoxies caused a setback to the Church one way or the other. The Pansophism ${ }^{6}$ of the 17 th century was designed to bring about a worldwide understanding and peace which is one of the fundamentals of theology.

From the $18^{\text {th }}$ century onward, the Church of England and other churches in the United Kingdom operated primary schools where Bible, catechism, reading, writing, and arithmetic were taught. In Nigeria, like other parts of Africa, education also came with religion and theology in the $19^{\text {th }}$ century with the missionaries, whose primary aim was to convert the pupils into their respective denominations. Mission education produced most of the first generation of political leaders in Africa?

${ }^{6}$ Pansophism means universal knowledge

7 I. A. Phiri; "Educational Practices as Christian Service in Africa"; in The Cambridge Dictionary of Christianity; edited by D. Patte; Cambridge: CUP; 2010; p. 357. 


\section{The Call into Administrative Post: A Biblical Example}

An administrator is the one whose job is to manage the affairs of the church either, as Pastor, Evangelist, Apostle, Prophet or Teacher. The sustainability of Christian values depends on standard theological education.

Jesus replied, "A man was going down from Jerusalem to Jericho, and he fell among robbers, who stripped him and beat him and departed, leaving him half dead. Now by chance a priest was going down that road, and when he saw him he passed by on the other side. So likewise a Levite, when he came to the place and saw him, passed by on the other side. But a Samaritan, as he journeyed, came to where he was, and when he saw him, he had compassion. He went to him and bound up his wounds, pouring on oil and wine. Then he set him on his own animal and brought him to an inn and took care of him. And the next day he took out two denarii and gave them to the innkeeper, saying, 'Take care of him, and whatever more you spend, I will repay you when I come back.' (Lk. 10:30-35).

Jesus was the one who told this parable to a lawyer who wanted to know who his neighbour was. In the parable, Jesus did not use symbols taken from the realm of nature or from custom but from actual occurrences. In the parable quoted above, the idea of education and administration featured in two areas: the Good Samaritan 'took care of him at the Inn and also gave the Inn Keeper certain amount of money to 'take care of him'. Origen, one of the $3^{\text {rd }}$ century Church Fathers allegorized the parable thus:

Jerusalem meaning "the vision of peace," was the seat of blessing, of history, of religion, of privilege. This was the City where God had chosen to place His name, the center of worship and communion with Himself. ${ }^{8}$ In other words, Jerusalem is a divine location.

Jericho was a very beautiful city for its situation and its palm trees but it was a cursed city (Jos 6:26).

The victim was humanity

The Good Samaritan was Jesus

The Robbers were demons

The Levite and the Priest represented the Law and the Prophets (unable to save the man)

The wine and oil used by the Good Samaritan as a first aid was the Word of God

The Ass which took the man to the Inn was the Holy Spirit which led sinners to the Church

The Inn represents the Church

The Inn Keeper was the Church Administrators who are the Pastor or Ministers of God generally

The two denariis were the Gifts of the Holy Spirit to care for the Sinners in the Church

It should be noted that the allegory of Origen was also used by Augustine of Hippo and may be too heavy for the intended meaning suggested by the context of the parable. It was clear in the parable that Jesus was answering a question raised by a lawyer "who is my neighbour?"(Lk.10:25ff) The Good Samaritan in the parable then becomes the neighbour of whoever needs his help. The parable does not suggest that Jesus is the good neighbour. However, the Inn keeper represents the Church Administrators (Ministers of God) who are commanded to 'take care' of the flock of Jesus. The Gifts of the Holy Spirit are given to them to be used in taking care of the sinners' spiritual wound but of course, 'Additional Whatever' will be used during the care service. This 'Additional Whatever' could be time spent, visitation when in trouble, financial help, or any other good positive support. It could also be theft, adultery, extortion, lies, and any other thing that may further injure them but Jesus promised to repay the 'whatever more, you spent as extras when he returns (Revelation 22:12). Apart from the command to take care, one of Jesus' last commandments in the famous 'Last Commission' was 'teaching them to observe all that I have commanded (taught or educated) you, (Matthew 28:20).

\section{Dangers Associating with Theological Illiteracy in Nigeria}

1. It leaves the Church administrator in the darkness of ignorance

2. It leaves the administrator in confusion when there is a failure

3. It makes the administrator to teach what he thinks instead of teaching what he was commanded to teach by the Head of the Church.

4. It places something else that is different from God at the centre of religious administrations

5. It weakens further the weak leader

6. It promotes error in religious practices

7. It damages instead of building the body of Christ

${ }^{8}$ H. Lockyer; All Parables of The Bible; Grand Rapids: Zondervan; 1963; p. 263. 
8. It leaves the administrator in darkness of foolishness

9. It damages further instead of repairing the damage done by others

10. It registers inferiority complex

11. It causes fear to a potentially bold preacher

12. It throws the administrator into unnecessary darkness

13. It provides foolish answers to wise and foolish questions

14. It promotes mockery against the administrator

15. It increases the disunity of the body of Christ

16. It maintains the alternative to God's standard in religiosity

17. It promotes fanaticism

Ignorance is a disease. My people are destroyed for lack of knowledge, says the Lord in Hosea 4:6. Spiritually speaking, ignorance is the father of all diseases peculiar to the Church Administrators. In fact, God himself declared that it is a killer virus (Hosea 4:6). Illiteracy is a disease as well as ignorance. He who remains ignorant remains in foolishness because he does not know what he is supposed to know because he refuses to acknowledge his ignorance. There are three kinds of ignorance:

1. Environmental or social ignorance (this is when one lacks the knowledge of his/her environment or the environment caused one to be ignorant)

2. Educational ignorance (this is simply an illiterate)

3. Spiritual ignorance (when one lacks spiritual knowledge)

In order for a Church administrator to have an effective ministry they must not be ignorant of any these. Many ministers today speak authoritatively in the areas where they are ignorant. For example, there are many theologians without theology. It is unlawful to find out that people with no good theological training are also teaching the Bible or Theology or even heading theological institutions. Some became pastors and teachers of theology because they are "PhD." holders in other disciplines. If a lawyer, who is already a 'SAN' is crossing from Law to Medicine, he will have to learn the Medicine from scratch; in the same way having a doctorate degree in Law, Mathematics etc does not qualify anyone as theologian. The course must be taken, the title, "theologian" should be used appropriately because it is a professional title like Lawyer, Doctor, Engineer, etc. It is necessary to study theology as a separate discipline, being a Professor of Mathematics, Economics, Geography, English, does not qualify anyone to become a lecturer in Theology in any University without a degree in Theology too. It is time that people stop messing up God's Institution through ignorance or without relevant qualifications. Lastly, every educational department should appreciate the impact of Religion and Theological Education and there should be immediate reappraisal of the activities of Religious and the Theological Departments in order for it to remain relevant.

\section{Conclusion}

Having explored the importance of Theological Education to Church Administrations in the context of Hosea 4:6 that said: "my people perish because the lack knowledge (that is, education) and 2 Peter1:5 which commanded: add to your faith virtue (ethics) and to virtue knowledge (education). It is therefore affirmed that if any administrator who fails to have theological education he/she will only be good at misleading people. Furthermore, if the importance of theological education and the danger of its ignorance is clearly understood, it is affirmed that Church administrations without theological education is a dangerous ministry which contradicts the Lord Jesus' instruction to "teach" since one can only teach what one has learnt and understood. It is also noted that many are still working as Church administrators without theological education under the pretence or umbrella of the gift of prophecy and direction of the Holy Spirit; such attitude is not part of the standard Christianity because Jesus, the founder of Christianity taught his disciples before commanding them to wait and receive the power that came with the package of the gift of prophecy and more.

Finally, it is concluded that Theological education should be given due respect by all other academic departments and there should be no more intrusion by experts of other subjects into Christian ministry without proper training in theology accordingly.

\section{References}

A. E. McGrath; Historical Theology: An Introduction to the History of Christian Thought; London: Blackwell; 1998; p. 2.

I. T. Ramsay; The Fourth R: The Durham Report on Religious Education; London: SPCK; 1970; p. 1.

I. A. Phiri; "Educational Practices as Christian Service in Africa"; in The Cambridge Dictionary of Christianity; edited by D. Patte; 
Cambridge: CUP; 2010; p. 357.

H. Lockyer; All Parables of The Bible; Grand Rapids: Zondervan; 1963; p. 263.

D. D. Adegbite ; A Concise Dictionary of Theology \& Philosophical Terminology Ibadan: BITBR, 2004.

S.O. Akinsulure; Christian Education For You, Duduyemi Comm. Press Ltd, 1995.

C. Brand et.al. eds, Hollman Illustrated Bible Dictionary, Tennessee, Hollman, 2004.

P. B Clarke; West African and Christianity; London: Amold; 1986.

J. N. D. Kelly; Early Church Doctrines; London: A\&C; Black; 1973.

J. A. Omoyajomo; et.al (eds), Maker of the Church in Nigeria; Lagos; CSS; 1995.

J. H. Bernard, The International Critical Commentary Vol. II , edited by A. H. MCNeile London, T \& T Clark 1928, p. 685.

H. J. M. Nouwen, In the Name of Jesus: Reflections on Christian Leadership, NY, Crossroad Pub. 2002, p.36.

A. Malphurs, Advanced Strategic Planning: A New Model for Church and Ministry Leaders, Grand Rapids, Baker Books, 2000, p. 79.

J.O. Adegbite, The Church is in Trouble: Where is the Saviour?, Gbongan, BIP, 2011, p.35. 